\title{
スクアレン環化酵素の生合成工学
}

阿 部 郁 朗 $a, b$

\section{Engineering of Squalene Cyclizing Enzymes}

\author{
Ikuro $\mathrm{ABE}^{a, b}$ \\ ${ }^{a}$ School of Pharmaceutical Sciences, University of Shizuoka, and ${ }^{b}$ PRESTO, Japan Science \\ and Technology Agency, 52-1 Yada, Suruga-ku, Shizuoka 422-8526, Japan
}

(Received April 28, 2008)

\begin{abstract}
The broad substrate tolerance and catalytic potential of squalene cyclizing enzymes of bacterial and plant origin are remarkable; the enzymes readily accept variety of non-physiological substrate analogues and efficiently perform sequential ring-forming reactions to produce a series of unnatural cyclic triterpenes. By utilizing the catalytic plasticity of the enzymes, it is possible to generate unnatural novel cyclic polyprenoids by enzymatic conversion of chemically synthesized substrate analogues. Here we present recent examples including (a) enzymatic formation of a "supra-natural" hexacyclic polyprenoid as well as heteroaromatic ring containing cyclic polyprenoids by bacterial squalene: hopene cyclase from Alicyclobacillus acidocaldarius, and (b) enzymatic cyclization of 22,23-dihydro-2,3-oxidosqualene and 24,30-bisnor-2,3-oxidosqualene by plant oxidosqualene: $\beta$-amyrin cyclase from Pisum sativum.
\end{abstract}

Key words_— squalene cyclase; oxidosqualene cyclase; triterpenes; enzyme; substrate specificity; engineered biosynthesis

\section{1. はじめに}

今後の医薬資源の開発について考えた場合，多様 性に富む化合物群をいかに効率よく生産し，創薬 シードとして提供できるかが鍵になる，二次代謝酵 素の中には，微妙な構造の違いで基質特異性や生成 物の構造が大きく変化するものがあり，これが天然 物の分子多様性を生み出す大きな要因になってい る。それゆえ，筆者は，二次代謝産物の基本骨格構 築を担う生合成鍵酵素の研究が, 多様な構造と生理 活性を示す天然物に匹敵するライブラリー構築に結 実し, 将来の創薬化学にかならずや貢献するものと 信じ，酵素触媒機能の拡張による非天然型新規化合 物の創出と, セレンディピティに頼らない合理的な 方法論の開発に取り組んでいる，本稿では，酵素触 媒機能の人為的な制御と分子多様性創出の格好のモ デルともいえる，ステロイドやトリテルペンの基本 骨格を構築するスクアレン環化酵素を取り上げる.

$a$ 静岡県立大学薬学部, $b$ 科学技術振興機構 PRESTO （广422-8526 静岡県静岡市駿河区谷田 52-1）

e-mail: abei@u-shizuoka-ken.ac.jp

本総説は, 平成 20 年度日本薬学会学術振興賞の受賞を 記念して記述したものである.
ポリエンの環化により複数の炭素-炭素結合と，複 数の不斉中心を一挙に構築する反応は, 自然界にお ける最も複雑な反応の 1 つであり, 有機合成化学の 技術が格段に進歩した今日においても，酵素のみが 唯一効率的に行うことが可能な反応として，半世紀 以上に渡って多くの有機化学者を魅了し続けてき た．筆者らは，化学的に合成した人工基質をプロー ブとして酵素に作用させることにより，微生物や植 物由来スクアレン環化酵素が，異例とも言える広範 な基質特異性と触媒ポテンシャルを示すことを明ら かにした。その結果，立体化学が厳密に制御された 超天然型 6 環性ステロイドやへテロ芳香環を含有す る非天然型トリテルペンなど，これまでに例のない 新たな化合物の生産に成功し, 酵素触媒機能の拡張 と新規分子骨格創出への展望を与えた，以下に，最 近の研究成果について紹介する.

\section{2. 微生物由来スクアレン環化酵素}

単純なイソプレン単位の繰り返し構造を持つ鎖状 のオキシドスクアレン(1)やスクアレン (2)を閉環し て，複数の不斉中心を持つ複雑なステロイドやトリ テルペンの基本骨格を一挙に構築する酵素は，バク テリアのような下等な生物から高等動物や植物に至 
(A)
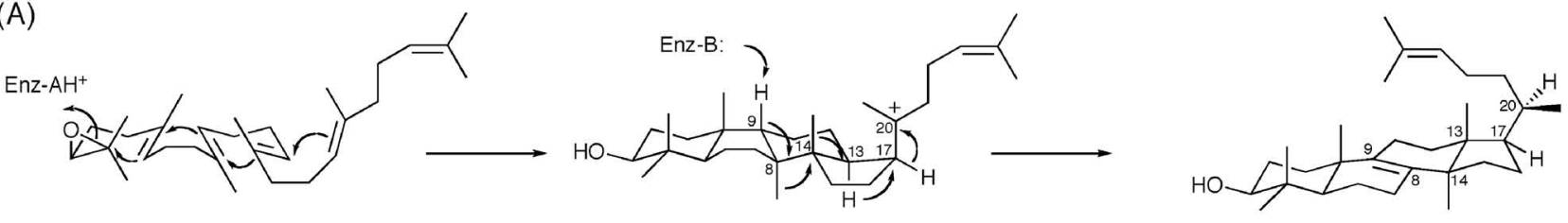

1

3

(B)

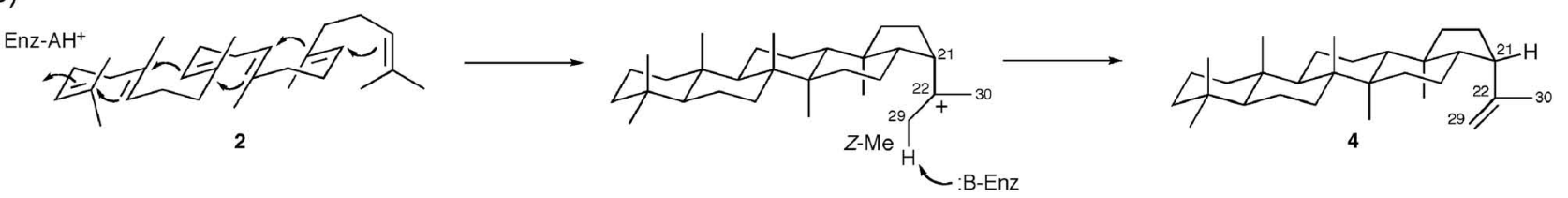

Fig. 1. Enzymatic Formation of (A) Lanosterol from (3S) 2,3-oxidosqualne by Animal OSC, and (B) Hopene from Squalene by Bacterial SHC

るまで, 生物界に広く分布し，しかも生物の進化の 度合に応じて，その閉環様式に大きな違いがあるこ とが知られている. ${ }^{1-7)}$ すなわち, 細胞膜の構成成 分として，動物におけるコレステロールの生合成中 間体となるラノステロール $(3)$ ，また，植物におけ るステロールの前駆体となるシクロアルテノールへ の閉環反応では， $(3 S)$-オキシドスクアレン $(\mathbf{1})$ が chair-boat-chair 型のコンフォメーションに取り込 まれ，末端エポキシ環が求電子攻撃を受けることに より開始される。.まず 4 環性のプロトステロール第 3 級カチオン中間体へ閉環ののち，メチル基と水素 の一連の転位反応がそれに続く [Fig. 1(A)]。一 方, 一部の微生物やシダ植物などの下等な生物で は，スクアレンがオキシドスクアレンに変換される ことなく，直接，ホペン(4)など，3位の酸素官能 基を欠く $\mathbf{5}$ 環性トリテルペンに閉環するが，この場 合反応はより安定な all-chair 型のコンフォメーシ ヨンを取って進行する [Fig. 1(B)].

このように，オキシドスクアレンとスクアレンは 各々異なる酵素により, 多様な骨格を持ったステ ロールやトリテルペンに変換されるが，こうした閉 環反応機構の差異が, 酵素タンパクのどのような構 造の違いによるものであるのか, 大変興味深いもの があり, 筆者も大学院博士課程に進学以来, スクア レン環化酵素の構造機能相関の解明をめざした生物 有機化学的研究に取り組んできた。今日ではこうし た閉環反応メカニズムの違いは, 酵素の活性中心構 造の微妙な変化によってもたらされるものと考えら れており, 最近の研究成果は, 高等生物のオキシド
スクアレン環化酵素（OSC）がより原始的な微生 物のスクアレン環化酵素（SC）から進化したとす る分子進化仮説を裏付けつつある. ${ }^{5)}$

スクアレンを all-chair 型のコンフォメーション に取り込んで単純に閉環する微生物由来 SC 酵素 は, 高等生物の OSC 酵素に比べて, より原始的な ものであると考えられてきた。 まず, 微生物の酵素 によるスクアレンの閉環は, 分子状酸素の取り込み を必要としない嫌気的な過程で，また，反応もより 単純で途中炭素骨格の転位はみられない。しかも, 微生物由来 SC 酵素の基質特異性は低く, 複雑な閉 環反応の化学を厳密に制御しなければならない高等 生物由来 OSC 酵素と比べて, それほど精巧なシス テムを必要とはしないようにも考えられる。逆に言 えばそれだけ，人工基質の酵素変換など生合成工学 の可能性を探る上で好都合であるとも言える。実 際, 微生物由来 SC 酵素が示す触媒ポテンシャルに は注目すべきものがあり, 例えば基質の一方の末端 二重結合を還元した人工基質を作用させた場合，閉 環反応の様式を劇的に変化させて，本来の生成物と は全く異なる骨格を持った化合物を高収率で生成す

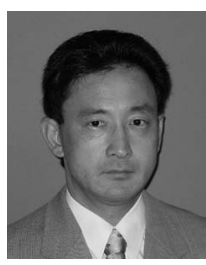

阿部郁朗
1984 年東京大学薬学部卒, 1989 年東京 大学大学院薬学系研究科博士課程修 了, 同年仏政府給費留学生, 1991 年二 ユーヨーク州立大学ストーニーブルッ ク校化学科上級博士研究員, 研究助教 授, 1996 年ユ夕大学医薬化学科研究助 教授, 1998 年静岡県立大学薬学部講師, 2008 年より准教授, 2005 年より科学技 術振興機構さきがけ兼任. 
ることなどを，これまでに筆者らは報告してき た. ${ }^{8,9)}$ しかも，こうした人工基質に対してさえ，䤉 素反応は酵素により厳密に制御されており，もう 1 つの複雑な環化反応の立体化学を厳密に制御するだ けの能力を既に持ち合わせていたことになる.

2-1. 超天然型 6 環性ステロイドの創出 中等 度好熱好酸菌 Alicyclobacillus acidocaldarius 由来木 ペン合成酵素は，これまでに最もよく研究がなされ ている SC 酵素である. ${ }^{1-3,7,10)}$ 高等動物や植物由来 OSC 酵素とは違って，組み替え酵素を大腸菌にお いて大量発現させることが可能で，しかも比較的安 定で取り扱いの容易な膜酵素である（室温に放置し ても安定で， $60^{\circ} \mathrm{C}, \mathrm{pH} 6.0$ の条件下で酵素活性を示 す). 既に，フライブルグ大学の Schulz 教授らのグ ループによって X 線結晶構造解析が報告されてお り, 11-13) 酵素活性部位を構成するアミノ酸残基や䤉 素反応機構の詳細などが明らかにされている．結晶 構造に基づけば，中心部の大きな活性部位キャビテ イには，鎖長の異なる基質アナログを受け入れるだ けの十分なスペースがあるものと予想され，したが って，天然型基質の場合と同様な酵素反応の進行が 予想される一方で，修飾基質の構造に対応して，酵 素活性部位におけるフォールディング・コンフォ メーションが影響を受け，在来みられないような骨 格を持つた生成物を与える可能性も期待される。 そ こで筆者らは， $\mathrm{C}_{35}, \mathrm{C}_{40}$ など鎖長の異なる一連の基 質アナログを化学合成し，酵素に作用させることに
よって，天然には存在しないような 6 環あるいは 7 環といった，高度な環構造を有する「超天然型ステ ロイド」の人為的な生産に挑戦した.

基質の合成は，文献記載の方法に基づき，ゲラニ オール $\left(\mathrm{C}_{10}\right)$ ，ファルネソール $\left(\mathrm{C}_{15}\right)$ ，ゲラニルゲ ラニルオール $\left(\mathrm{C}_{20}\right)$ などを原料としてカップリン グ反応を行うことにより, 非天然型の $\mathrm{C}_{25}\left(=\mathrm{C}_{15}+\right.$ $\left.\mathrm{C}_{20}\right), \mathrm{C}_{30}\left(=\mathrm{C}_{10}+\mathrm{C}_{20}\right), \mathrm{C}_{35}\left(=\mathrm{C}_{15}+\mathrm{C}_{20}\right), \mathrm{C}_{40}\left(=\mathrm{C}_{20}\right.$ $+\mathrm{C}_{20}$ ）アナログを合成した。これを大腸菌におい て大量発現させ精製した A. acidocaldarius 由来木 ペン合成酵素（SHC）に作用させ，酵素反応生成 物を有機溶媒で抽出，TLC や逆相 HPLCにより分 離精製ののち，各種 NMR $\left({ }^{1} \mathrm{H},{ }^{13} \mathrm{C},{ }^{1} \mathrm{H}-{ }^{1} \mathrm{H} \quad \mathrm{COSY}\right.$, HMQC，HMBC，NOESY，NOE 差スペクトル）や MS スペクトルなどを測定して構造解析を行った.

試行錯誤の結果，イソプレン単位が $3+4$ の形で 連結した $\mathrm{C}_{35}\left(=\mathrm{C}_{15}+\mathrm{C}_{20}\right)$ アナログ $(\mathbf{5})$ を作用させ た場合，これまでに全く例のない 6/6/6/6/6/5 環構 造を有する 6 環性の非天然型新規化合物 (6) (収率 10\%）が，単一生成物として得られることを見い出 した [Fig. 2(A)].14) しかも驚いたことに，閉環反 応の立体化学は酵素によって厳密に制御されており,

6 個の炭素-炭素結合と 11 個の不斉中心を一挙に構 築する，すなわち，酵素反応は本来の基質であるス クアレン $\left(\mathrm{C}_{30}=\mathrm{C}_{15}+\mathrm{C}_{15}\right)$ の場合と同様に, $\mathrm{C}_{15}$ フ アルネシル単位の側から進行する [Fig. 2(B)]。こ れに対して, 反対側の $\mathrm{C}_{20}$ ゲラニルゲラニル単位の
(A)

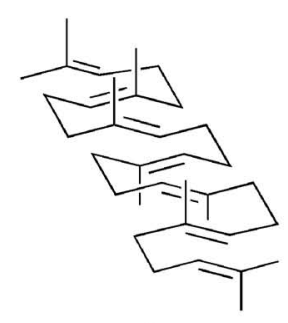

5

(B)

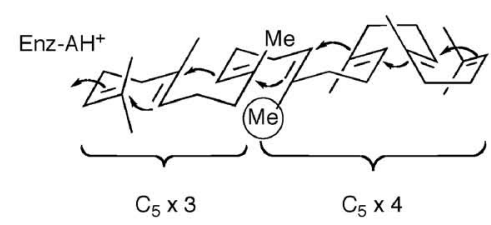

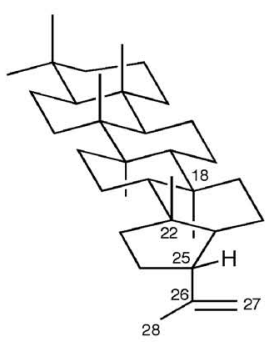
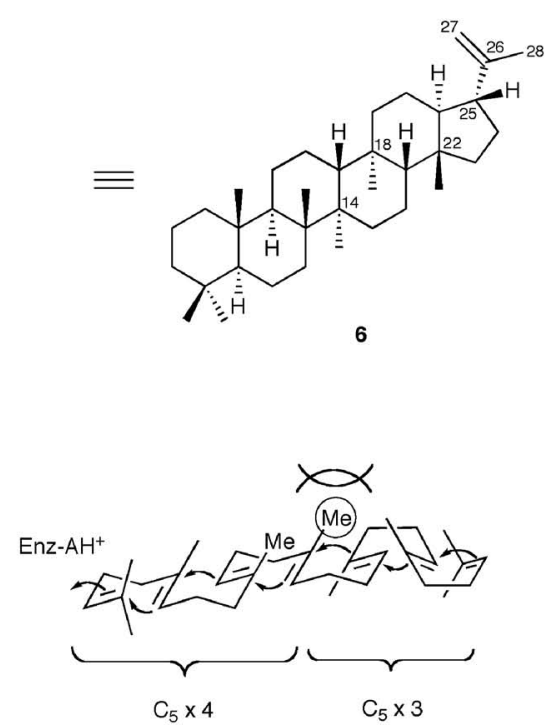

Fig. 2. Enzymatic Formation of "Supra-natural" 6/6/6/6/6/5 Hexacyclic Polyprenoid by A. acidocaldarius SHC 
側から環化が進行した場合には，C 環形成の段階で 14 位のメチル基が $\beta$ の配置をとることになり，立 体障害により閉環反応の進行が妨げられてしまう. 次に，フォールディングについてみると，酵素反応 生成物 6 の 22 位のメチル基が $\beta$-axial, 25 位のイソ プロペニル基が $\alpha$-axial の配置を取ることから，基 質が chair-chair-chair-chair-boat-boat 型のコンフォ メーションを取って反応が進行しなければならな い。また，反応は本来の生成物であるホペンの場合 と同様に，炭素骨格の転位を伴わず，最終的に H-27 プロトンが特異的に引き抜かれて二重結合を 形成して終結する。このような炭素数が 5 つも多い 人工基質に対してさえも，炭素鎖の末端に至るま で，閉環反応の立体化学が酵素によって厳密に制御 されている点は特筆に值する。しかも，このような 分子骨格を持った化合物はこれまでに例がなく，ス テロイドはホルモンやビタミンなど細胞内情報伝達 において中心的役割を演じる生体機能分子であるた め，その生物活性についても大いに興味がもたれる ところである.

一方， $\mathrm{C}_{35}$ アナログに対して， $\mathrm{C}_{15}$ ファルネシル 単位を含まない $\mathrm{C}_{30}\left(=\mathrm{C}_{10}+\mathrm{C}_{20}\right)$ や $\mathrm{C}_{40}\left(=\mathrm{C}_{20}+\mathrm{C}_{20}\right)$ アナログからは，2 環性の閉環生成物が得られるの みで，多環形成反応の進行はみられなかった。この ことから，A. acidocaldarius 由来 SHC による 3 環 以上の高度な環形成反応が進行するためには，C 環 形成の段階で核間 pro-C14 メチル基が $\alpha$ 配置を取 る必要があり, したがって基質における $\mathrm{C}_{15}$ ファル ネシル単位の存在が重要であることが示唆され た. ${ }^{14)}$

2-2. ヘテロ芳香環含有非天然型ステロイドの創 出次に筆者らは，より多くの生理活性が期待で きる、へテロ芳香環を部分構造に持つ非天然型ステ ロイドの生産をめざして，インドール環を含有する 2 つの基質アナログ 3-(geranylgeranyl) indole(7) と 3- (farnesyldimethylallyl) indole $(\mathbf{8})$ を新たに合成し て，A. acidocaldarius 由来 SHC を用いた酵素変換 を試みた [Fig. 3(A), 3(B)]. ${ }^{15)}$ このうち，インドー ル 3 位に $\mathrm{C}_{20}$ ゲラニルゲラニル単位が結合した 7 の エポキシ体 3- ( $\omega$-oxidogeranylgeranyl) indole (11) は，シロイヌナズナ (Arabidopsis thaliana) 由来 ルペオール合成酵素（OSLuC）と反応させた場合, 多環形成反応が進行して 6/6/6/6/6/5 縮合環構造を
有する 6 環性のインドール含有ジテルペン petromindole (12)（天然からカビ毒として単離報告され ている）を生成することが [ (Fig. 3 (D)]，ライス 大学の Matsuda 教授らのグループによって報告さ れている. ${ }^{16)}$ しかし，興味深いことにA. acidocaldarius 由来 SHC は 7 を基質として全く受け入れ ず，両酵素間の活性部位構造の違いが示された。 上 述したように，A. acidocaldarius 由来 SHC による 3 環以上の環形成反応が進行するためには，やはり $\mathrm{C}_{15}$ ファルネシル単位の存在が不可欠であることが 改めて示唆された。結晶構造に基づくとホペンのC 環及び D 環部分近傍に位置する，立体的に嵩高 い，活性中心キャビティ構成アミノ酸残基 Ile261 の存在による立体障害がその原因として推察される [Fig. 3(C)]. ${ }^{15)}$

一方，イソプレン単位が $3+1$ の形で連結した基 質 8 からは，6/6/5 環構造を有する 3 環性のイン ドール含有非天然型新規化合物が主生成物 (10) （収 率 5\%）として，また，6/6 環構造を有する 2 環性 の新規化合物が副生成物 (9) (収率 3\%) として得 られた [Fig. 3(B)]。この場合，閉環反応は基質が chair-chair-chair 型のコンフォメーションを取って 進行し，立体的に嵩高い，電子過剰な，インドール 環の存在により，3 環性，あるいは，2 環性力チ才 ン中間体が生成した段階で多環形成反応が中断して しまうものと考えられる。すすなわち，6/6/5 環構造 の 3 環性力チオン中間体から, 一連の転位反応 $\left(\mathrm{H}-13 \beta \rightarrow 14, \mathrm{CH}_{3}-8 \beta \rightarrow 13 \beta, \mathrm{CH}_{3}-9 \alpha \rightarrow 8 \alpha\right)$ \& $\mathrm{H}-11$ プロトンの引き抜きが進行すれば主生成物 $\mathbf{1 0}$ を, また，6/6 環構造の 2 環性カチオン中間体から，転 位反応 $\left(\mathrm{H}-9 \alpha \rightarrow 8 \alpha, \mathrm{CH}_{3}-10 \beta \rightarrow 9 \beta, \mathrm{CH}_{3}-5 \alpha \rightarrow 10 \alpha\right)$ と H-6 プロトンの引き抜きが進行すれば副生成物 9 を与えることになる $[$ Fig. 3(B)]，両者の場合と も，一連の転位反応の立体化学と特定のプロトンの 引き抜きは，やはり酵素によって厳密に制御されて いる.

同様な結果が，ピロールを含有する合成基質，2(geranylgeranyl) pyrrole と 2-(farnesyldimethylallyl) pyrrole を用いた酵素変換実験でも得られている17)。 $\mathrm{C}_{20}$ ゲラニルゲラニル単位が結合したアナログが $A$. acidocaldarius 由来 SHC の基質として受け入れな かったのに対して, 後者の $\mathrm{C}_{15}$ ファルネシル単位を 含む基質からは，6/6/5 環構造を有する 3 環性のピ 
(A)

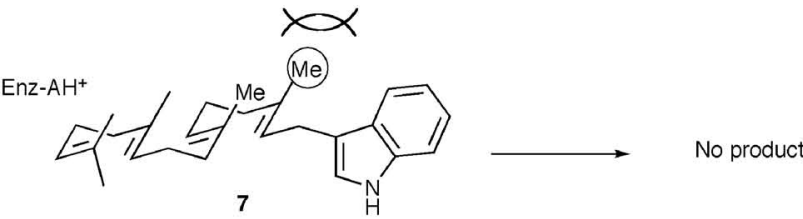

(B)

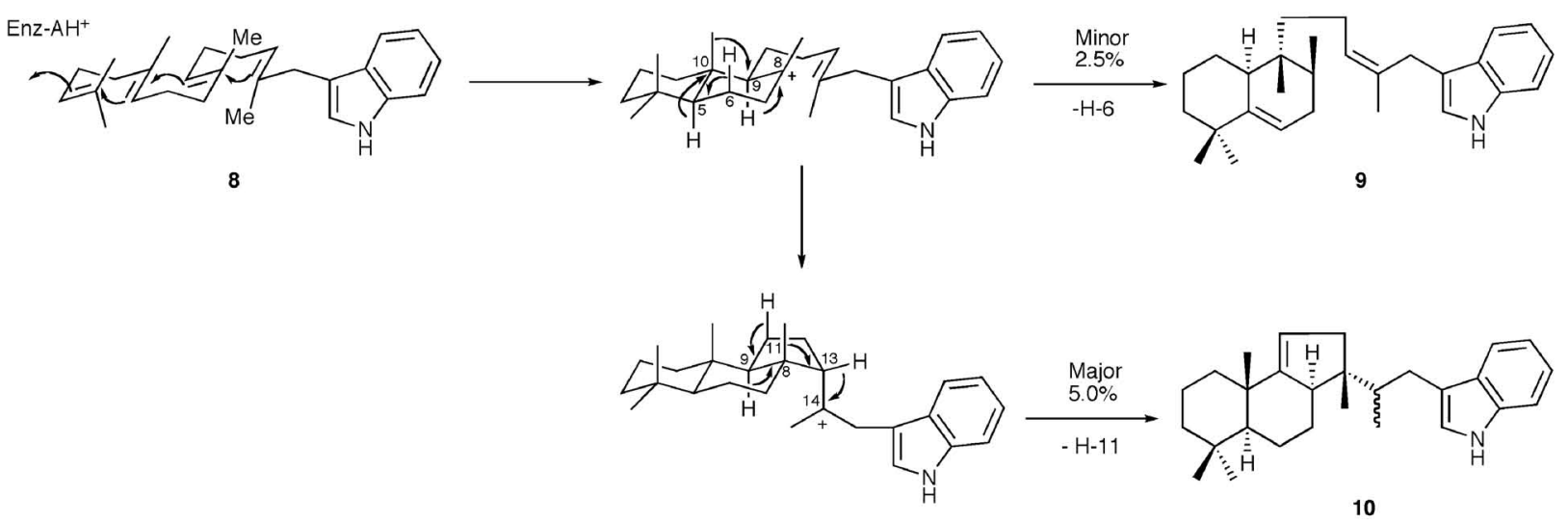

(C)

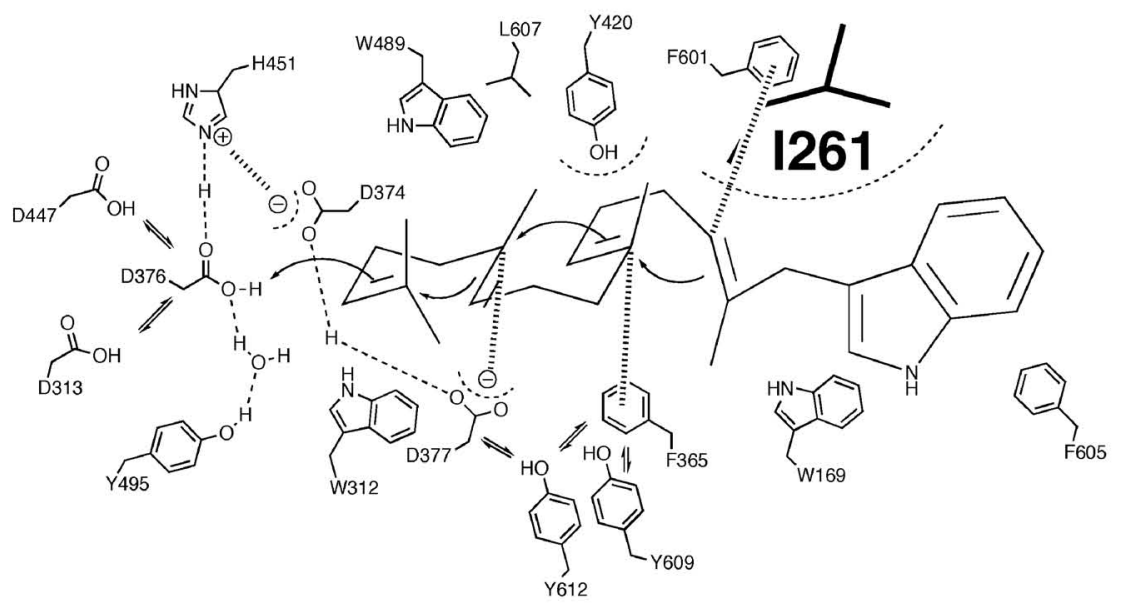

(D)

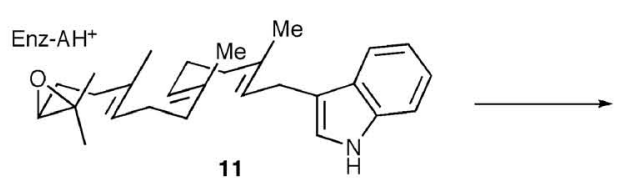

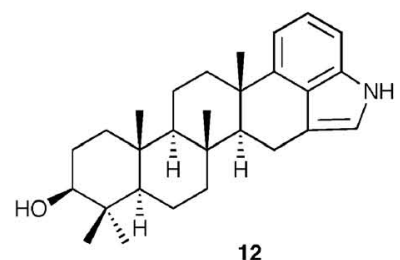

Fig. 3. (A) and (B) Enzymatic Cyclization of Indole-ring Containing Substrates Analogues by A. acidocaldarius SHC, (C) Proposed Interactions between the Active-site Amino Acid Residues of $A$. acidocaldarius SHC and 3-(Farnesyldimethylallyl) indole, and (D) Enzymatic Formation of Petromindole by $A$. thaliana OSLuC

ロール含有非天然型新規化合物が主生成物（収率 1 \%)として，また，6/6 環構造を有する 2 環性の新 規化合物が副生成物（収率 $0.1 \%$ ) として得られた。

ここでピロール含有生成物の酵素反応収率は，イン ドールの場合に比べて $20 \%$ 程度に減少している
が，これは立体的にサイズの大きい， $\pi$ 電子に富む インドールの方が，より小さなピロールに比べて， 酵素活性中心キャビティを構成するアミノ酸残基と の間の $\pi-\pi$ 電子相互作用などにより，活性部位に よりよく適合して，高い親和性を示すことによるも 
のと考えられる.

2-3. メチリデン基含有基質アナログの酵素変換 微生物由来 SC 酵素による多環形成反応の立体化 学に与える影響を調べる目的で，スクアレンのメチ ル基の代わりにビニル基を導入した 4 種の $\mathrm{C}_{31}$ 基質 アナログ ; 1-, 25-, 26-, 27-methylidenesqualene(MS) を化学合成し, 大腸菌において大量発現させ精製し た A. acidocaldarius 由来 SHC に作用させることに より，酵素反応生成物の単離と構造解析を行った (Fig. 4).

まず，末端メチル基にメチリデン基を導入した， 1-MS（13）及び 25-MS（14）からは，共通の 5 環性の ホペン誘導体 (17)（収率各 35,38\%）が得られ，木 ペンにおける $\mathrm{E}$ 環形成の酵素反応機構を考える上 で重要な知見を得た。 ${ }^{18)}$ すなわち，通常スクアレン からホペンが生成する際には，末端の Z-メチル基 の側から位置選択的に脱プロトン化が進行して二重 結合を形成し，反応が終結することが知られている が [Fig. 1(B)]，1-MS 及び 25-MS を基質とした場 合には，電子供与性のメチリデン基の存在により 5 環性の C-22 第 3 級カチオン中間体が途中で安定化 され，その結果，H-29 プロトンの引き抜きが起こ る以前に，C-21-C-22 結合に関する側鎖の回転が進 行する可能性が示された [Fig. 4(A)].

次に, 26-MS (15) 及び 27-MS (16) も, 同様に $A$. acidocaldarius 由来 SHC の基質として受け入れら れ，6/6/6/5+6 環構造を有するユニークな新規骨 格をもつ $\mathrm{C}_{31}$ ダンマレン誘導体（18）（収率 $10 \%$ ） （全く同一の骨格を持つ非天然型ダンマレン誘導体 が，高等動物由来 OSC 酵素との反応で得られてい る）とホペン誘導体（19）（収率 $0.3 \% ）$ の生成がそ れぞれ認められ [Fig. 4(B)，4(C) ]，19) これにより 微生物由来 SC 酵素が示す広範な基質特異性と触媒 ポテンシャルが改めて認識されるところとなった.

一方，筆者らが以前報告した高等動物由来 OSC 酵 素の場合と同様に，閉環反応中間体のカチオン中心 の $\alpha$ 位にメチリデン基を配置することにより，反 応途中で生成するアリルカチオン中間体が，活性中 心の求核性アミノ酸残基によりトラップされ，共有 結合を形成して，自殺基質として機能する可能性も

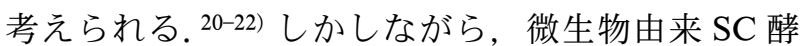
素においては，そのような不可逆的な酵素阻害は観 察されず，両生物間の酵素活性部位構造の違いが示
(A)

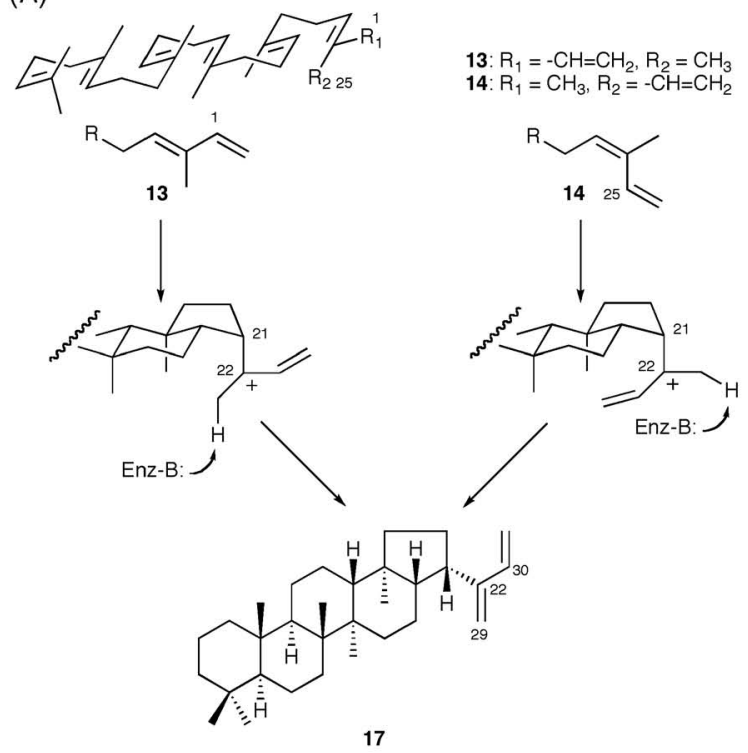

(B)

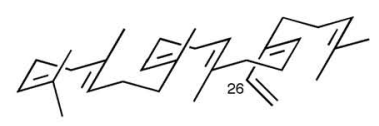

(C)
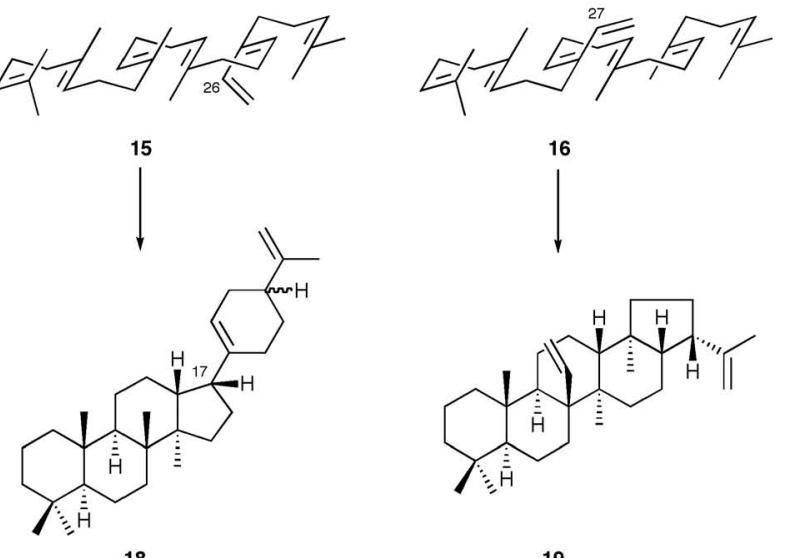

19

Fig. 4. Enzymatic Cyclization of Methylidene-extended Substrate Analogues by $A$. acidocaldarius SHC

された.

\section{3. 植物由来オキシドスクアレン環化酵素}

高等植物に広く分布する $\beta$-アミリン $(\mathbf{2 0})$ の生合 成については，1955 年にチューリッヒ工科大学の Ruzicka一門が「生合成イソプレン則」で提唱した ように，オキシドスクアレン (1)が chair-chairchair-boat 型のコンフォメーションに取り込まれ, 6/6/6/5 環構造の 4 環性のダンマレンカチオン中間 体を生成ののち，D環や $\mathrm{E}$ 環の環拡大など，一連 の複雑な炭素骨格の転位を経て，8 個の不斉中心を 有する $6 / 6 / 6 / 6 / 6$ 環構造の 5 環性の $\beta$-アミリン骨 格を形成するものと考えられている (Fig. 5). ${ }^{4}$ 実 際にこの反応を触媒する $\beta$-アミリン合成酵素（OS- 


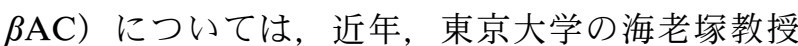
のグループにより, 酵素遺伝子のクローニングや, キメラ酵素及び部位特異的変異酵素の機能解析など が報告されている. ${ }^{23,24)}$ しかし，酵素の結晶化はい まだ達成されておらず，酵素活性中心構造の詳細な どについては今後の研究が待たれているのが現状で ある，そこで筆者らは，さらなる多環形成反応機構 の解明と非天然型新規化合物の酵素合成をめざして, 2 つの末端メチル基を欠損させた 24,30-bisnor-2,3oxidosqualene（BNOS）（21）と，末端二重結合を還 元した 22,23-dihydro-2,3-oxidosqualene (DHOS) （25）を，いずれもラセミ体として化学合成し，酵母 に異種発現したエンドウマメ由来 OS $\beta$ AC に作用さ せることにより，酵素反応に及ぼす効果を検討し た. ${ }^{25,26)}$

3-1. ビスノルオキシドスクアレンの酵素変換 $\beta$-アミリンの骨格構築において, BNOS (21)にお ける 2 つの末端メチル基の欠損が， $\mathrm{E}$ 環形成にどの
ような影響を及ぼすか興味がもたれるところであ る。実際に酵母に異種発現したエンドウマメ（Pisum sativum) 由来 OS $\beta \mathrm{AC}$ に作用させたところ, 主生成物として 5 環性の 6/6/6/6/6 環構造を有する 非天然型トリテルペン bisnor- $\beta$-amyrin（22）（収率

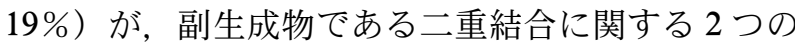
位置異性体 bisnorgermanicol(23)（収率 7\%）， bisnor- $\delta$-amyrin (24)（収率 1\%）とともに得られるこ とが示された（Fig. 5) ${ }^{25)}$ (ハーバード大学の Corey 教授らも 1968 年の論文で，エンドウマメ種子芽生 えの粗酵素抽出液を用いて, BNOS から bisnor- $\beta$ amyrin の生成を報告している27)）。

そこで筆者らはさらに， $\mathrm{E}$ 環形成反応機構の解明 を目的として，安定同位体で標識した $\left[23-{ }^{13} \mathrm{C}\right]$-及 び $\left[23,23-{ }^{2} \mathrm{H}\right]-\mathrm{BNOS}$ を別途合成し，酵素反応を行 って，NMR スペクトルにおける $\alpha$ シフトや $\beta$ シフ トなどアイソトープ効果を詳細に解析した結果, 生 成物の $\mathrm{C}-19$ が選択的に ${ }^{13} \mathrm{C}$ 標識されること，また，
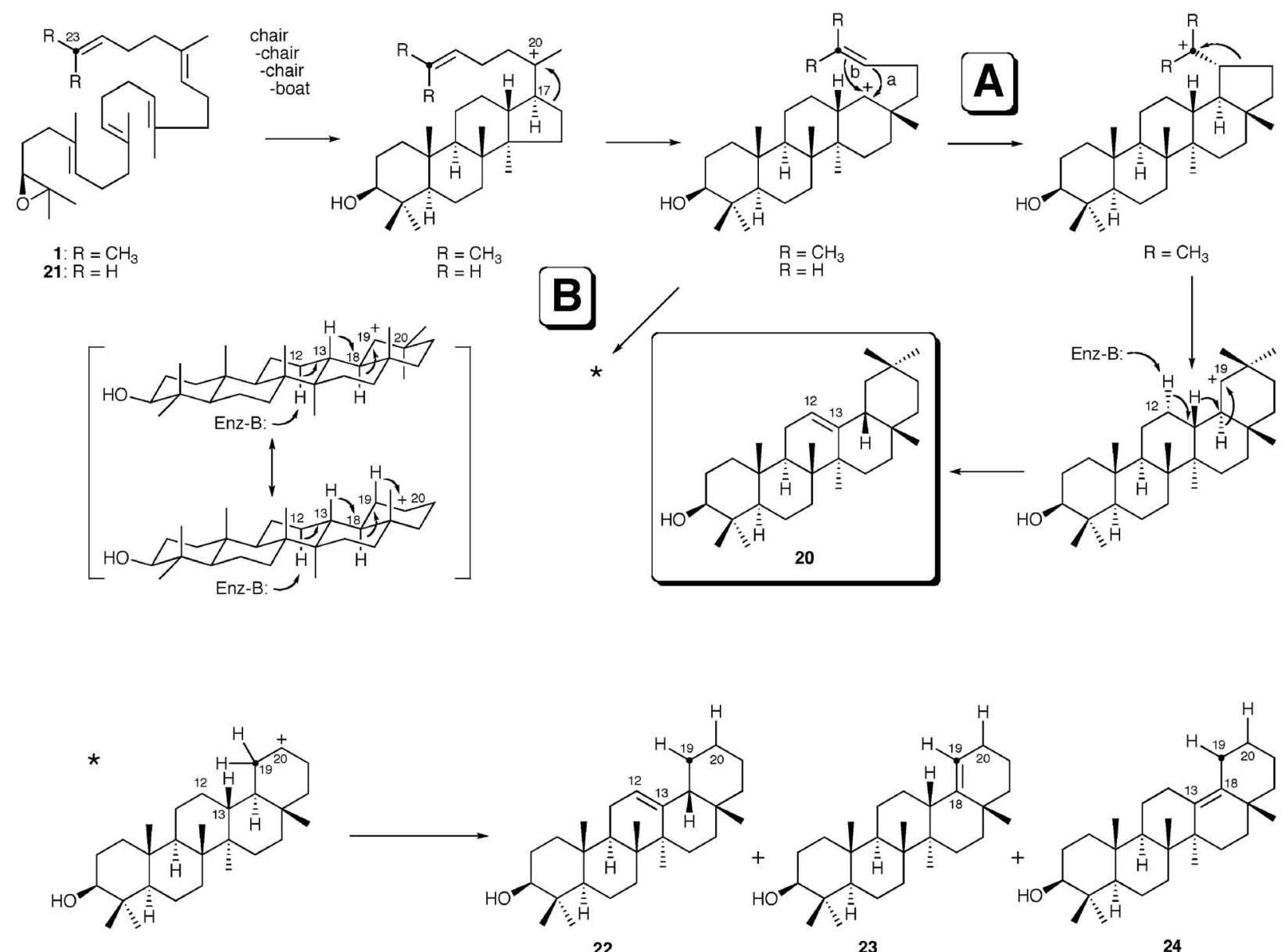

Fig. 5. Enzymatic Formation of $\beta$-Amyrin, and Enzymatic Cyclization of Bisnoroxidosqualene by P. sativum OS $\beta$ AC 
C-19 と C-20 が特異的に ${ }^{2} \mathrm{H}$ 標識されることが示さ れ， $\mathrm{E}$ 環形成の反応機構を考える上で重要な知見を 得た（Fig. 5).25) すなわち, 酵素反応生成物の標識 パターンから，ビスノル・アミリンへの閉環反応 は，末端义チル基の欠損により第 1 級力チオンとな るビスノル・ルパニルカチオンを経由する A の ルートではなく, 熱力学的により安定で, $\mathrm{E}$ 環がひ ずみのより少ない 6 員環構造を取るビスノル・オレ アニル第 2 級カチオンの生成を経由する B のルー トで，特異的に進行することが示された。一方，

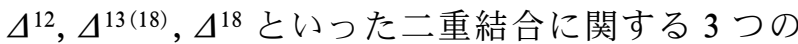
位置異性体の生成は，最終段階のビスノル・オレア ニル C-20 カチオン中間体以降の転位反応が酵素に よって厳密には制御され得ないことを示唆してい る。本来の $\beta$-アミリンの生成においては，オレア ニル C-19 カチオン (all-chair 型コンフォメーショ ン）においてアンチパラレル型の 2 回の 1,2-ヒドリ ド転位（H-18 $\alpha \rightarrow 19 \alpha, H-13 \beta \rightarrow 18 \beta)$ が進行するの に対し, ビスノル・アミリンの生成では, 3 回の 1,2-ヒドリド転位（H-19 $\beta \rightarrow 20 \beta, H-18 \alpha \rightarrow 19 \alpha, H-$ $13 \beta \rightarrow 18 \beta$ ）が進行することになる（Fig. 5)。この 際，2つの末端メチル基の欠損によつて，酵素活性 部位におけるビスノル・オレアニル C-20 カチオン 中間体の $\mathrm{E}$ 環部分のフォールディングに摇らぎを 生じ，その結果，転位反応が完全な形で進行せず， 複数の生成物を与えたものと推察される.

3-2. ジヒドロオキシドスクアレンの酵素変換 オキシドスクアレンの末端二重結合を還元した DHOS (25) を酵素に作用させた場合，どのような骨 格を持つ生成物を与えるのか興味がもたれるところ である。.まず，最初に生成するはずのカチオン中間 体の $\mathrm{D}$ 環は, 熱力学的により安定な 5 員環構造を 取るのか，それとも，6員環への環拡大が進行する のか. そして次に何が起こるか？ 水和反応やプロ トンの脱離など様々な可能性が考えられる，実際に エンドウマメ由来 $\mathrm{OS} \beta \mathrm{AC}$ を用いて酵素反応を行つ たところ，驚いたことに閉環反応の様式を劇的に変 化させて，本来の生成物である 5 環性の $\beta$-アミリ ンとは全く異なる骨格を持った， 2 種の非天然型 4 環性トリテルペンを生成することを見い出した。す なわち，主生成物として，D環が 5 員環で 7 位の 二重結合と $20 R$ の立体配置を取る euph-7-en-3 $\beta$-ol （26）（収率 4\%）が，また，副生成物として，D 環
が 6 員環で 12 位に二重結合をもつ bacchar-12-en$3 \beta$-ol（27）（収率 1\%）が得られた（Fig. 6). ${ }^{26)} 20$ 位の立体化学を含む構造決定については，天然より 得られた eupha-7,24-dien-3 $\beta$-ol と bacchara-12,24dien-3 $\beta$-ol の側鎖二重結合を接触還元して得た化合 物をそれぞれ標品として，スペクトルデータが完全 に一致することから確認した。6/6/6/6 環構造を有 する 4 環性のバッカレン骨格を持つトリテルペンの 酵素合成としてはこれが最初の例である.

いずれの場合も閉環反応の立体化学は酵素によつ て瑗密に制御されており，主生成物 euph-7-en-3 $\beta$ ol(26)への反応では，より熱学的に安定な，6/6/6/ 5 環構造を有する 4 環性の第 3 級力チオン中間体か ら，一連の転位反応 $(\mathrm{H}-17 \alpha \rightarrow 20 \alpha, \mathrm{H}-13 \beta \rightarrow 17 \beta$, $\left.\mathrm{CH}_{3}-14 \alpha \rightarrow 13 \alpha, \mathrm{CH}_{3}-8 \beta \rightarrow 14 \beta\right)$ と $\mathrm{H}-7$ プロトンの引 き抜きが進行して，C-20Rの立体化学を達成す る。一方, 副生成物 bacchar-12-en-3 $\beta$-ol(27) につい ては，D 環拡大によりバッカレニル第 2 級カチオ ン中間体を生成ののち，転位反応 $(H-13 \beta \rightarrow 18 \beta)$ と H-12 プロトンの引き抜きが進行するものと考え られる。ここで，末端二重結合の $\pi$ 電子の供与な しに, anti-Markovnikov 型の D 環拡大反応が進行 する点は有機化学的にも大変重要な知見である。ま た，上述したように，スクアレンから 5 環性のテト ラヒマノールを生成する原生動物 Tetrahymena pyriformis 由来 SC 酵素に，2,3-dihydrosqualene を 作用させた場合にも，全く同一の骨格を有する eu-

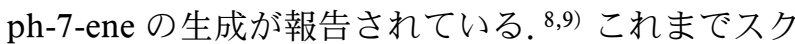
アレン環化酵素の反応生成物の多様性は，酵素活性 中心構造の微妙な変化によってもたらされるものと 考えられてきたが，これら酵素においては，もう 1 つの複雑なポリエン環化反応の立体化学を制御する だけのポテンシャルを既に持ち併せていたことにな る。一方，オタネニンジン (Panax ginseng) 由来 $\mathrm{OS} \beta \mathrm{AC}$ の $\mathrm{W} 259 \mathrm{~L}$ 点変異酵素が， $\beta$-アミリンに加 えて, eupha-7,24-dien-3 $\beta$-ol を産生することも報告

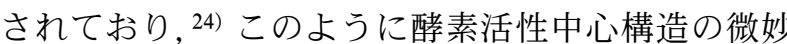
な変化や基質の修飾が，酵素による閉環反応の様式 を劇的に変化させる点は注目に值する。

\section{4. おわりに}

植物や微生物由来スクアレン環化酵素が示す広範 な基質特異性と触媒ポテンシャルには特筆に值す る。今後さらに新たに設計した合成人工基質の酵素 


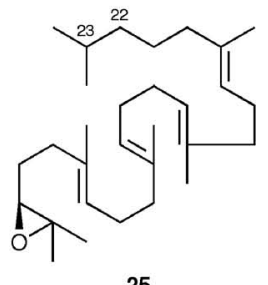

25
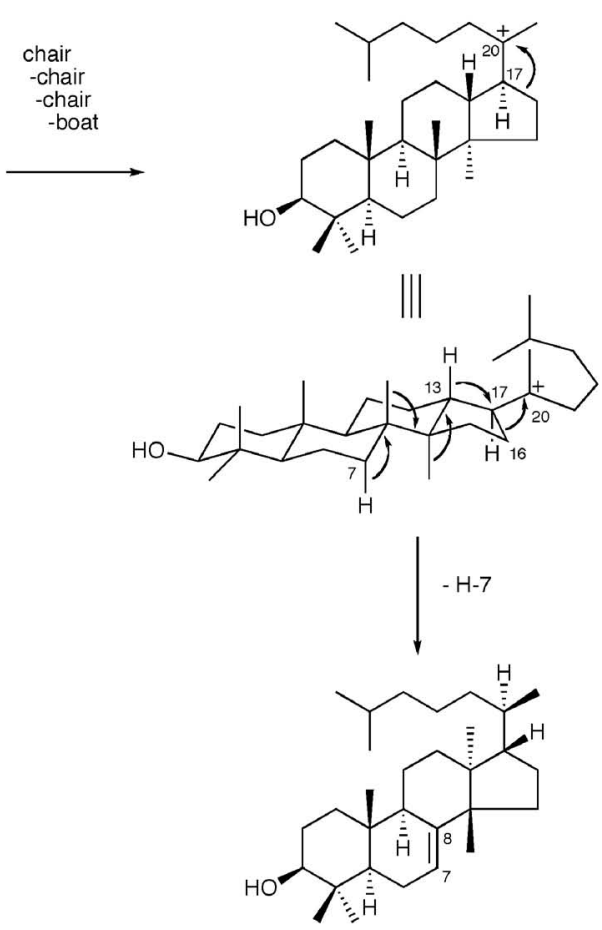

26
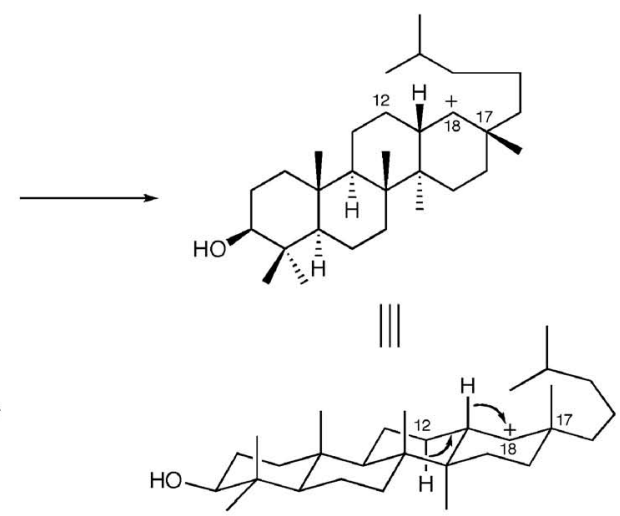
$-12$

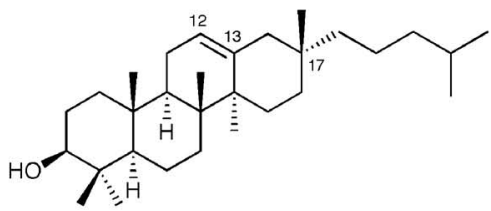

27

Fig. 6. Enzymatic Cyclization of Dihydrooxidosqualene by P. sativum OS $\beta$ AC

変換とともに，結晶構造に基づく合理的な変異の導 入による酵素触媒機能の拡張により，これまで以上 の分子多様性と新たな生物活性を備えた「超天然型」 化合物ライブラリーの構築が可能になる，ステロイ ドホルモンやビタミン, サポニンや強心配糖体, さ らにフシジン酸など抗生物質を例に挙げるまでもな く，クアレン環化䤉素の反応生成物及びその代謝産 物は，その多様な構造及び生物活性から，これまで 実際に医薬品, 農薬, 食品添加物などに幅広く応用 されているが，今後益々その重要性が増し，新たな 展開がみられるものと期待される.

最後に，これら生合成酵素が触媒する反応は，有 機合成の技術が格段に進歩した今日にあっても，酵 素のみが唯一効率よく行うことの可能なものであ る、クリーンかつマイルドな条件下，驚くほど単純 な工程で，複雑な分子骨格を作り上げることができ る. 保護・脱保護あるいは官能基変換の繰り返しを 必要としない，生体触媒を用いた合成法の利点は計 り知れないものがあり，次世代の環境調和型の新合 成手法の発展にかならずや大きな貢献をするものと 期待される。
謝辞 本稿執筆に当たり, 静岡県立大学薬学 部・野口博司教授をはじめとする共同研究者の諸先 生，並びに，大学院生・学生諸氏に厚く御礼申し上 げます。また，学生時代に生合成研究に魅せられて 研究室の門をたたいて以来, 終始ご指導ご鞭撻を賜 りました恩師，東京大学薬学部名誉教授・三川 潮 先生, 東京大学大学院薬学系研究科教授・海老塚 豊先生に深く感謝致します。本研究は，文部科学 省, 日本学術振興会, 並びに, 科学技術振興機構の 研究助成により行われたものであり，ここに厚く御 礼申し上げます。

\section{REFERENCES}

1) Abe I., Rohmer M., Prestwich G. D., Chem. Rev., 93, 2189-2206 (1993).

2) Abe I., Nat. Prod. Rep., 24, 1311-1331 (2007).

3) Wendt K. U., Schulz G. E., Corey E. J., Liu D. R., Angew. Chem. Int. Ed., 39, 2812-2833 (2000).

4) Eschenmoser A., Ruzicka L., Jeger O., Arigoni D., Helv. Chim. Acta, 38, 1890-1904 (1955). 
5) Ourisson G., Rohmer M., Poralla K., Annu. Rev. Microbiol., 41, 301-333 (1987).

6) Xu R., Fazio G. C., Matsuda S. P. T., Phytochemistry, 65, 261-291 (2004).

7) Hoshino T., Sato T., Chem. Commun., 291301 (2002).

8) Abe I., Rohmer M., J. Chem. Soc., Chem. Comm., 902-903 (1991).

9) Abe I., Rohmer M., J. Chem. Soc., Perkin Trans. I, 783-791 (1994).

10) Poralla K., "Comprehenisve Natural Products Chemistry," Vol 2., eds. by Barton D. H. R., Nakanishi K., Pergamon, New York, 1999.

11) Wendt K. U., Poralla K., Schulz G. E., Science, 277, 1811-1815 (1997).

12) Wendt K. U., Lenhart A., Schulz G. E., J. Mol. Biol., 286, 175-187 (1999).

13) Reinert D. J., Balliano G., Schulz G. E., Chem. Biol., 11, 121-126 (2004).

14) Abe I., Tanaka H., Noguchi H., J. Am. Chem. Soc., 124, 14514-14515 (2002).

15) Tanaka H., Noguchi H., Abe I., Org. Lett., 7, 5873-5876 (2005).

16) Xiong Q., Zhu X., Wilson W. K., Ganesan A., Matsuda S. P. T., J. Am. Chem. Soc., 125, 9002-9003 (2003).
17) Tanaka H., Noma H., Noguchi H., Abe I., Tetrahedron Lett., 47, 3085-3089 (2006).

18) Tanaka H., Noguchi H., Abe I., Org. Lett., 6, 803-806 (2004).

19) Tanaka H., Noguchi H., Abe I., Tetrahedron Lett., 45, 3093-3096 (2004).

20) Abe I., Prestwich G. D., J. Biol. Chem., 269, 802-804 (1994).

21) Abe I., Prestwich G. D., Proc. Natl. Acad. Sci. U.S.A., 92, 9274-9278 (1995).

22) Abe I., Dang T., Zheng Y.-F., Madden B. A., Feil C., Poralla K., Prestwich G. D., J. Am. Chem. Soc., 119, 11333-11334 (1997).

23) Kushiro T., Shibuya M., Ebizuka Y., J. Am. Chem. Soc., 121, 1208-1216 (1999).

24) Kushiro T., Shibuya M., Masuda K., Ebizuka Y., J. Am. Chem. Soc., 122, 6816-6824 (2000).

25) Abe I., Sakano Y., Sodeyama M., Tanaka H., Noguchi H., Shibuya M., Ebizuka Y., J. Am. Chem. Soc., 126, 6880-6881 (2004).

26) Abe I., Sakano Y., Tanaka H., Lou W., Noguchi H., Shibuya M., Ebizuka Y., J. Am. Chem. Soc., 126, 3426-3427 (2004).

27) Corey E. J., Gross S. K., J. Am. Chem. Soc., 89, 4561-4562 (1967). 